\title{
Pengaruh FED rate, inflasi, dan indeks NIKKEI 225 terhadap IHSG di Indonesia (2016-2017)
}

\author{
Joventus Partogi Silaen*; Haryadi; Emilia \\ Prodi Ekonomi Pembangunan Fak. Ekonomi dan Bisnis Universitas Jambi \\ *E-mail korespodensi: joventus2@gmail.com
}

\begin{abstract}
This study aims to analyze the influence and look at the Fed Rate, Inflation in Indonesia, and the NIKKEI 225 Index on the Composite Stock Price Index (JCI). The data used in this study is secondary data obtained from Bank Indonesia, Investing.com, library sources, journals, and other scientific articles. The analytical method used in this study is the multiple linear regression analysis method using the Ordinary Least Square (OLS) method. Data is processed using software using monthly data with the research period from January 2016-December 2017 sourced from the internet, scientific journals, and books. The results of this study indicate that partially the FED Rate variable has a negative effect on the JCI, Inflation has a negative effect on the JCI, and the NIKKEI 225 Index has no effect on the NIKKEI 225 Index. Meanwhile, simultaneously all variables affect the JCI.
\end{abstract}

Keywords: Fed Rate, Inflation, NIKKEI 225 Index, IDX

\begin{abstract}
Abstrak
Penelitian ini bertujuan untuk menganalisis pengaruh dan melihat perkembangan variabel Fed Rate, Inflasi yang ada di Indonesia, dan Indeks NIKKEI 225 terhadap Indeks Harga Saham Gabungan (IHSG). Data yang digunakan dalam penelitian ini adalah data sekunder yang diperoleh dari Bank Indonesia, Investing.com, sumber pustaka, jurnal, dan artikelartikel ilmiah lainnya. Metode analisis yang digunakan dalam penelitian ini adalah metode analisis regresi linear berganda menggunakan metode Ordinary Least Square (OLS) yang datanya di olah dengan menggunakan Software dengan menggunakan data perbulan dengan Periode penelitian mulai dari Januari 2016-Desember 2017 yang datanya bersumber dari internet,jurnal ilmiah, dan buku. Hasil dari penelitian ini menunjukan bahwa secara parsial variabel FED Rate berpengaruh negatif terhadap IHSG, Inflasi berpengaruh negatif terhadap IHSG dan Indeks NIKKEI 225 tidak berpengaruh tehadap Indeks NIKKEI 225. Sedangkan secara simultan seluruh variabel bepengaruh terhadap IHSG.
\end{abstract}

Kata kunci: FED rate, Inflasi, Indeks NIKEEI 225, IHSG

\section{PENDAHALUAN}

Perkembangan ekonomi dalam suatu negara secara singkat dapat dilihat dari perkembangan pasar modal yang baik dan industri-industri sekuritasnya. Pasar modal (bursa efek) adalah tempat bertemunya antara pihak yang memiliki kelebihan dana dengan pihak yang membutuhkan dana dengan cara memperjualbelikan sekuritas, Tandelilin 
(2007). Dengan adanya pasar modal, pihak yang memiliki kelebihan dana dapat menginvestasikan dana tersebut dengan harapan memperoleh keuntungan (return), sedangkan perusahaan (issuer) dapat memanfaatkan dana tersebut untuk kepentingan investasi tanpa menunggu tersedianya dana operasional perusahaan. Menurut Jogiyanto (2010), investasi didefinisikan sebagai penundaan konsumsi sekarang untuk dimasukan ke aktiva produktif selama periode waktu tertentu. Bentuk investasi yang dilakukan investor di pasar modal dapat dibedakan menjadi dua yaitu investasi langsung dan tidak langsung. Apabila suatu investasi dilakukan dengan membeli secara langsung aktiva keuangan dari perusahaan baik melalui perantara maupun yang lain, maka disebut Investasi langsung. Apabila suatu investasi dilakukan dengan cara membeli saham dari perusahaan investasi yang mempunyai portofolio aktiva-aktiva keuangan dari perusahaan-perusahaan lain, maka disebut investasi tidak langsung. Tersedia banyak pilihan untuk berinvestasi di pasar modal.

Berbagai pilihan investasi tersebut diantaranya yaitu saham, obligasi, reksadana, dan instrumen derivatif (opsi dan futures). Di antara instrumen pasar modal tersebut yang paling populer saat ini adalah saham. Saham adalah surat bukti kepemilikan atas suatu perusahaan, Tandelilin (2007). Berbagai peristiwa ataupun kebijakan yang dilakukan pemerintah dapat memberi dampak terhadap perekonomian dan iklim investasi. Apabila suatu peristiwa mengakibatkan meningkatnya return saham berarti peristiwa tersebut direspon positif oleh para pelaku ekonomi atau pelaku pasar, sehingga suatu kebijakan pemerintah menjadi efektif saat kebijakan tersebut direspon positif oleh investor. Sebaliknya, kebijakan tersebut menjadi tidak efektif jika kebijakan tersebut direspon negatif oleh investor, oleh karena itu tingkat risiko investasi di pasar modal lebih tinggi daripada investasi pada perbankan.

Ada beberapa kondisi dan situasi yang menentukan suatu saham itu akan mengalami fluktuasi, yaitu kondisi mikro dan makro ekonomi, kebijakan perusahaan dalam memutuskan untuk ekspansi (perluasan usaha), seperti membuka kantor cabang (brand office), kantor cabang pembantu (sub brand office) baik yang dibuka di domestic maupun luar negri. Resiko sistematis yaitu suatu bentuk resiko yang terjadi secara menyeluruh dan telah ikut menyebabkan perusahaan ikut terlibat, efek dari psikologi pasar yang ternyata mampu menekan kondisi teknikal jual beli saham. Berdasarkan penjelasan diatas dapat diketahui bahwa Tingkat Suku Bunga FED Rate, Inflasi, Indeks NIKKEI 225 merupakan faktor-faktor yang mempengaruhi Indeks Harga Saham Gabungan pada Bursa Efek Indonesia pada tahun 2016-2017 dapat diterima secara umum. Berdasarkan latar belakang tersebut maka peneliti ini menganalisis tentang "Pengaruh FED Rate, Inflasi, Dan Indeks Nikkei 225, Terhadap IHSG Di Indonesia (2016-2017)"

\section{METODE}

Jenis data yang digunakan dalam penelitian ini adalah data sekunder . Data sekunder adalah data yang diperoleh atau dikumpulkan peneliti dari berbagai sumber yang telah ada. Penelitian ini bersifat peneltian kuantitatif, data kuantitatif adalah data yang berbentuk angka. Data yang digunakan dalam penelitian ini adalah data dalam bentuk time series pada periode Januari 2016-Desember 2017 yang diambil setiap bulannya. Sumber data penelitian ini berasal dari Bank Indonesia,RTI Business,Investing.com, sumber pustaka, refrensi dan jurnal. 
Metode penelitian ini menggunakan metode Deskriptif Kuantitatif. Penelitian Deskriptif Kuantitatif merupakan penelitian yang bertujuan menjelaskan fenomena yang ada dengan menggunakan angka-angka untuk mencandarkan karakteristik individu atau kelompok, Syamsudin \& Damiyanti (2011). Penelitian ini menilai sifat dari kondisi-kondisi yang tampak. Tujuan dalam penelitian ini dibatasi untuk menggambarkan karakteristik sesuatu sebagaimana adanya.

Alat analisis data yang digunakan dalam penelitian ini adalah analisis regresi linear berganda. Pengertian analisis regresi linier berganda menurut Sugiyono (2010), Analisis yang digunakan peneliti, bila bermaksud meramalkan bagaimana keadaan (naik turunnya) variable dependen (kriterium), bila dua atau lebih variable independen sebagai faktor predictor dimanipulasi (dinaik turunkan nilainya).

Fungsi Regresi :

$$
\text { IHSG }=\alpha_{0}+\beta_{1} \text { FR }+\beta_{2} \text { INF }+\beta_{3} \mathrm{NIKK}+\varepsilon
$$

\section{HASIL DAN PEMBAHASAN}

\section{FED rate}

Menurut kaum klasik, suku bunga menentukan besarnya tabungan maupun investasi yang akan dilakukan dalam perekonomian yang menyebabkan tabungan yang tercipta pada penggunaan tenaga kerja penuh akan selalu sama yang dilakukan oleh pengusaha. beranjak dari teori ekonomi mikro, teori klasik mengatakan bahwa tingkat bunga merupakan nilai balas jasa dari modal. Dalam teori klasik, stok barang modal dicampuradukkan dengan uang dan keduanya dianggap mempunyai hubungan subtitusif. Semakin langka modal, semakin tinggi suku bunga. Sebaliknya, semakin banyak modal semakin rendah tingkat suku bunga, Nasution dalam Badriah Sappewali (2001).

\section{Inflasi}

Inflasi didefinisikan sebagai kecenderungan dari harga-harga untuk menaik secara umum dan terus menerus, Boediono (2001). Kenaikan harga dari satu atau dua macam barang saja tidak dapat dikatakan sebagi Inflasi kecuali kenaikan tersebut membawa dampak terhadap kenaikan harga sebagian besar barang-barang lain. Secara garis besar ada tiga kelompok teori Inflasi, masing-masing teori ini menyatakan aspek-aspek tertentu dari proses Inflasi dan masingmasing bukan teori Inflasi yang lengkap mencakup semua aspek penting dari proses kenaikan harga. Ketiga teori itu adalah: Teori Kuantitas, Teori Keynes dan Teori Strukturalis. Menurut Kuncoro (1998), Inflasi adalah kecenderungan dari harga untuk meningkat secara umum dan terus menerus. kenaikan harga.

\section{Indeks NIKKEI 225}

Nikkei 225 adalah sebuah indeks pasar saham untuk Bursa Saham Tokyo (Tokyo Stock Exchange - TSE). Indeks ini telah dihitung setiap hari oleh surat kabar Nihon Keizai Shimbun (Nikkei) sejak tahun 1950. Indeks ini adalah harga rata-rata tertimbang (dalam satuan yen), dan komponennya ditinjau ulang setahun sekali. Saat ini Nikkei adalah indeks rata-rata ekuitas Jepang yang paling banyak dikutip, sebagaimana demikian pula dengan Dow Jones Industrial Average di Amerika Serikat. Bahkan dahulu antara 1975-1985, Nikkei 225 pernah dikenal dengan sebutan "Dow Jones Nikkei Stock Average". Hasil 
penelitian yang dilakukan oleh Witjaksono (2010) menunjukkan bahwa Indeks Nikkei 225 berpengaruh positif dan signifikan terhadap IHSG. Dari hal tersebut Indeks NIKKEI 225 diduga dapat berpengaruh terhadap IHSG.

\section{Perkembangan IHSG fed rate, inflasi, indeks nikkei 225}

\section{Perkembangan IHSG}

IHSG adalah salah satu indeks pasar saham yang digunakan oleh Bursa Efek Indonesia (BEI), sebagai indikator pergerakan harga saham yang mencakup pergerakan seluruh harga saham biasa dan saham preferen yang tercatat di Bursa Efek Indonesia (BEI).

Tabel 1. Perkembangan IHSG

\begin{tabular}{lcc}
\hline \multicolumn{1}{c}{ Tahun } & Nilai(Point) & Perkembangan (\%) \\
\hline Januari-2016 & 4615.16 & - \\
Februari-2016 & 4770.96 & 3,38 \\
Maret-2016 & 4845.37 & 1,56 \\
April-2016 & 4838.58 & $-0,14$ \\
Mei-2016 & 4796.87 & $-0,86$ \\
Juni-2016 & 5016.65 & 4,58 \\
July-2016 & 5215.99 & 3,97 \\
Agustus-2016 & 5386.08 & 3,26 \\
September-2016 & 5364.80 & $-0,40$ \\
Oktober-2016 & 5422.54 & 1,08 \\
November-2016 & 5148.91 & $-5,05$ \\
Desember-2016 & 5296.71 & 2,87 \\
Januari-2017 & 5294.10 & $-0,05$ \\
Februari-2017 & 5386.69 & 1,75 \\
Maret-2017 & 5568.11 & 3,37 \\
April-2017 & 5658.30 & 1,62 \\
Mei-2017 & 5378.15 & $-4,95$ \\
Juni-2017 & 5829.71 & 8,40 \\
July-2017 & 5840.94 & 0,19 \\
Agustus-2017 & 5864.06 & 0,40 \\
September-2017 & 5900.85 & 0,63 \\
Oktober-2017 & 6005.78 & 1,78 \\
November-2017 & 5952.14 & $-0,89$ \\
Desember-2017 & 6355.65 & 6,78 \\
\hline Rata-rata & $\mathbf{5 4 0 6 . 3 8}$ & $\mathbf{1 , 4 5}$ \\
\hline Sumber: & &
\end{tabular}

Sumber: IDX, 2019 (diolah)

Periode penelitian, rata-rata nilai IHSG adalah 5406.38 dan rata-rata perkembangan IHSG adalah 1,4 persen. Nilai IHSG Tertinggi berada pada bulan Desember 2017, hal ini disebabkan karena kondisi perekonomian Indonesia cenderung stabil dan stagnan sepanjang tahun 2017, dan puncaknya pada bulan Desember 2017, sehingga penguatan IHSG banyak didukung oleh profitabilitas korporasi yang terus meningkat. Kemudian nilai IHSG terendah berada di bulan Januari 2016, hal ini disebabkan oleh beberapa faktor, salah 
satunya adalah adanya teror bom pada 14 Januari 2016 di Jakarta, hal ini menimbulkan panic selling oleh investor. Perkembangan IHSG tertinggi berada pada bulan Desember 2017 yaitu 6.7 persen, dan terendah pada bulan November 2016 yaitu $-5,05$ persen.

\section{Perkembangan indeks NIKKEI 225}

Penelitian ini yang dipakai penulis adalah Indeks NIKKEI 225. Indeks NIKKEI 225 Nikkei 225 merupakan indeks yang paling banyak dikutip dari bursa saham Tokyo, Namanya diambil dari surat kabar Nikkei yang mulai menghitung indeks di tahun 1950

Tabel 2. Perkembangan Indeks NIKKEI 225

\begin{tabular}{|c|c|c|}
\hline Tahun & Nilai(Point) & Perkembangan (\%) \\
\hline Januari-2016 & 17518.30 & 0 \\
\hline Februari-2016 & 16026.76 & $-8,51 \%$ \\
\hline Maret-2016 & 16758.67 & $4,57 \%$ \\
\hline April-2016 & 16666.05 & $-0,55 \%$ \\
\hline Mei-2016 & 17234.98 & $3,41 \%$ \\
\hline Juni-2016 & 15575.92 & $-9,63 \%$ \\
\hline July-2016 & 16569.27 & $6,38 \%$ \\
\hline Agustus-2016 & 16887.40 & $1,92 \%$ \\
\hline September-2016 & 16449.84 & $-2,59 \%$ \\
\hline Oktober-2016 & 17424.02 & $5,92 \%$ \\
\hline November-2016 & 18308.48 & $5,08 \%$ \\
\hline Desember-2016 & 19114.37 & $4,40 \%$ \\
\hline Januari-2017 & 19041.34 & $-0,38 \%$ \\
\hline Februari-2017 & 19118.99 & $0,41 \%$ \\
\hline Maret-2017 & 18909.26 & $-1,10 \%$ \\
\hline April-2017 & 19196.74 & $1,52 \%$ \\
\hline Mei-2017 & 19650.57 & $2,36 \%$ \\
\hline Juni-2017 & 20033.43 & $1,95 \%$ \\
\hline July-2017 & 19925.18 & $-0,54 \%$ \\
\hline Agustus-2017 & 19646.24 & $-1,40 \%$ \\
\hline September-2017 & 20356.28 & $3,61 \%$ \\
\hline Oktober-2017 & 22011.61 & $8,13 \%$ \\
\hline November-2017 & 22724.96 & $3,24 \%$ \\
\hline Desember-2017 & 22764.94 & $0,18 \%$ \\
\hline Rata-rata & 18663.07 & $1,23 \%$ \\
\hline
\end{tabular}

Sumber: Investing, 2019 (diolah)

Perkembangan Nilai Indeks NIKKEI 225, nilainya cenderung mengalami kenaikan dan penurunan, atau nilainya berfluktuatif. Nilai tertinggi Indeks NIKKEI 225 berada di bulan Desember 2017, hal ini disebabkan karena sebanyak 171 dari 225 saham menguat, Saham Perbankan menjadi pendorong utama kenaikan saham indeks NIKKEI 225, dan pelemahan Yen juga mengakibatkan nilai Indeks NIKKEI 225 menguat, karena Investor 
mendapatkan laba yang lebih banyak. Nilai Indeks NIKKEI 2295 terendah berada di bulan juni 2016, hal ini disebabkan karena adanya isu "Brexit" (Britania Exit).

\section{Perkembangan inflasi}

Inflasi adalah kenaikan harga barang-barang secara umum secara terus menerus dalam waktu yang tidak dapat ditentukan dan berada pada level yang tinggi. Dalam tingginya inflasi di suatu negara maka akan berdampak negatif kepada investasi pula. Hal ini biasanya disebabkan karena apabila harga - harga barang dan jasa yang ada di pasaran sangat tinggi maka kecenderungan masyarakat untuk mengkonsumsi akan barang dan jasa akan berkurang.

Tabel 3. Perkembangan inflasi

\begin{tabular}{llc}
\hline \multicolumn{1}{c}{ Tahun } & Nilai(\%) & Perkembangan $(\boldsymbol{\%})$ \\
\hline Januari-2016 & 4.14 & 0 \\
Februari-2016 & 4.42 & 0,063348 \\
Maret-2016 & 4.45 & 0,006742 \\
April-2016 & 3.60 & $-0,23611$ \\
Mei-2016 & 3.33 & $-0,08108$ \\
Juni-2016 & 3.45 & 0,034783 \\
July-2016 & 3.21 & $-0,03738$ \\
Agustus-2016 & 2.79 & $-0,15054$ \\
September-2016 & 3.07 & 0,091205 \\
Oktober-2016 & 3.31 & 0,072508 \\
November-2016 & 3.58 & 0,075419 \\
Desember-2016 & 3.02 & $-0,18543$ \\
Januari-2017 & 3.49 & 0,13467 \\
Februari-2017 & 3.83 & 0,088773 \\
Maret-2017 & 3.61 & $-0,06094$ \\
April-2017 & 4.17 & 0,134293 \\
Mei-2017 & 4.33 & 0,036952 \\
Juni-2017 & 4.37 & 0,009153 \\
July-2017 & 3.88 & $-0,12629$ \\
Agustus-2017 & 3.82 & $-0,01571$ \\
September-2017 & 3.72 & $-0,02688$ \\
Oktober-2017 & 3.58 & $-0,03911$ \\
November-2017 & 3.30 & $-0,08485$ \\
Desember-2017 & 3.61 & 0,085873 \\
\hline Rata-rata & $\mathbf{3 . 6 7}$ & $\mathbf{- 0 , 0 0 8 7 7}$ \\
\hline Sumber & &
\end{tabular}

Sumber: Bank Indonesia, 2019 (diolah)

Perkembangan Inflasi di Indonesia pada Januari 2016 - Februari 2017 menunjukan kecenderungan yang rendah setiap bulannya. Dimana Indonesia memiliki peningkatan maupun penurunan yang berbeda beda setiap bulannya. Tingkat inflasi tertinggi di Indonesia selama periode Januari 2016 - Desember 2017 adalah pada bulan Maret-2016 mencapai 4,45 persen, hal ini disebabkan oleh kenaikan harga cabai dan bawang akibat terhambatnya musim panen. Rata-rata nilai tingkat Inflasi di Indonesia adalah sebesar 3,67 
persen, dan rata-rata nilai perkembangan Inflasi adalah sebesar $-0,00877$ persen. Perkembangan tertinggi Inflasi berada di bulan Januari 2017, dan terendahnya pada agustus 2017 Dengan demikian dapat disimpulkan tingkat Inflasi perbulan dari Januari 2016 Desember 2017 cenderung mengalami kenaikan dan penurunan, atau berfluktuatif, akan tetapi tingkat Inflasi pada 2 Tahun ini dapat dikatakan Inflasi Ringan.

\section{Perkembangan $F E D$ rate}

Menurut kaum klasik, suku bunga menentukan besarnya tabungan maupun investasi yang akan dilakukan dalam perekonomian yang menyebabkan tabungan yang tercipta pada penggunaan tenaga kerja penuh akan selalu sama yang dilakukan oleh pengusaha. FED Rate adalah tingkat suku bunga yang dikeluarkan oleh Bank Sentral Amerika Serikat (Federal Reserve System). Lembaga ini didirikan pada tahun 1913. Perkembangan fed rate dapat dilihat pada Tabel 4.

Tabel 4. Perkembangan FED rate

\begin{tabular}{lcr}
\hline Tahun & Nilai $(\boldsymbol{\%})$ & Perkembangan (\%) \\
\hline Januari-2016 & 0.50 & 0 \\
Februari-2016 & 0.50 & 0 \\
Maret-2016 & 0.50 & 0 \\
April-2016 & 0.50 & 0 \\
Mei-2016 & 0.50 & 0 \\
Juni-2016 & 0.50 & 0 \\
July-2016 & 0.50 & 0 \\
Agustus-2016 & 0.50 & 0 \\
September-2016 & 0.50 & 0 \\
Oktober-2016 & 0.50 & 0 \\
November-2016 & 0.50 & 0 \\
Desember-2016 & 0.75 & 0,333333 \\
Januari-2017 & 0.75 & 0 \\
Februari-2017 & 0.75 & 0 \\
Maret-2017 & 1.00 & 0 \\
April-2017 & 1.00 & 0,333333 \\
Mei-2017 & 1.00 & 0 \\
Juni-2017 & 1.25 & 0 \\
July-2017 & 1.25 & 0 \\
Agustus-2017 & 1.25 & 0 \\
September-2017 & 1.25 & 0 \\
Oktober-2017 & 1.25 & $\mathbf{0 , 0 4 3}$ \\
November-2017 & 1.25 & 0,166667 \\
Desember-2017 & 1.50 & $\mathbf{0 . 8 2}$ \\
Rata-rata & & 0
\end{tabular}

Sumber: Investing, 2019 (diolah)

Perkembangan FED Rate cenderung mengalami tren yang meningkat, kemudian perubahan tingkat suku bunganya dari bulan ke bulan tidak begitu signifikan atau tidak terlalu besar dengan rata-rata nilai FED Rate sebesar 0,82\%, dan rata-rata 
perkembangannya adalah sebesar 0,043\%. Nilai FED Rate Tertinggi berada di bulan Desember 2017, hal ini disebabkan oleh terus meningkatnya inflasi dikarenakan rendahnya angka pengangguran, oleh sebab itu The FED menaikan FED Rate untuk menaikan Inflasi, dan Kemudian nilai FED Rate terendah berada di bulan Januari 2016, yaitu sebesar 0,50\%, angka ini sama seperti pada bulan sebelumnya yaitu bulan Desember 2015.

\section{Pengaruh $F E D$ rate, Inflasi, dan Indeks Nikkei 225 terhadap IHSG}

Berikut ini hasil dari metode analisa dan perhitungan yang dilakukan melalui program Eviews 9 dengan tingkat signifikansi $\alpha=5 \%$ maka diperoleh persamaan regresi sebagai berikut :

Tabel 5. Hasil regresi

\begin{tabular}{crcrr}
\hline \multicolumn{1}{c}{ Variable } & Coefficient & Std. Error & t-Statistic & \multicolumn{1}{c}{ Prob. } \\
\hline C & 9.088815 & 1.431625 & 6.348599 & 0.0000 \\
FED & 0.245625 & 0.046289 & 5.306310 & 0.0000 \\
INFLASI & -0.058948 & 0.014811 & -3.980108 & 0.0007 \\
LNNIKKEI & -0.049110 & 0.147619 & -0.332682 & 0.7428 \\
\hline R-squared & 0.884010 & Mean dependent var & 8.591912 \\
Adjusted R-squared & 0.866611 & S.D. dependent var & 0.084596 \\
S.E. of regression & 0.030896 & Akaike info criterion & -3.965347 \\
Sum squared resid & 0.019092 & Schwarz criterion & -3.769004 \\
Log likelihood & 51.58416 & Hannan-Quinn criter. & -3.913257 \\
F-statistic & 50.80953 & Durbin-Watson stat & 1.324432 \\
Prob(F-statistic) & 0.000000 & & \\
\hline
\end{tabular}

Sumber: Data diolah, 2019.

Berdasarkan hasil regresi diatas, maka dapat diperoleh persamaan sebagai berikut :

LNIHSG $=9.088815+0.245625$ FED -0.058948 INFLASI -0.049110 LNNIKKEI $+e$

Tabel 6. Probablitas variabel

\begin{tabular}{cc}
\hline Variabel & Probabilitas \\
\hline FED & 0.0000 \\
INFLASI & 0.0007 \\
LNNIKKEI & 0.7428 \\
\hline
\end{tabular}

Sumber: Data diolah, 2019.

\section{Uji statistik}

\section{Uji f-statistik}

Dari hasil pengujian diperoleh nilai $F_{\text {hitung }}$ sebesar 50.80953 dengan tingkat kepercayaan 95\% $\alpha=5 \% / 0,05$ diperoleh nilai $F$ tabel sebesar 3,10 hasil regresi menunjukkan $\mathrm{F}$ hitung $>\mathrm{F}$ tabel maka (Ho) ditolak dan (Ha) diterima artinya secara bersama-sama FED Rate, Infllasi, dan Indeks NIKKEI 225 berpengaruh signifikan terhadap Indeks Harga Saham Gabungan (IHSG) periode Januari 2016-Desember 2017. Pengujian ini membuktikan bahwa secara bersama-sama akan berpengaruh signifikan terhadap IHSG 


\section{Uji t-statistik}

\section{Fed rate}

Tingkat kepercayaan 95\%, $\alpha=5 \% / 0,05$. Dan nilai Probabilitas 0.0000. Maka $0,05>0.0000$, hal ini berarti bahwa variabel FED Rate berpengaruh signifikan terhadap Indeks Harga Saham Gabungan (IHSG) .

\section{Inflasi}

Dengan tingkat kepercayaan 95\%, $\alpha=5 \% / 0,05$. Dan nilai Probabilitas 0.0007, Maka $0,05>0.0007$, hal ini berarti bahwa variable Inflasi berpengaruh signifikan terhadap Indeks Harga Saham Gabungan (IHSG).

\section{Nikkei 225}

Dengan tingkat kepercayaan 95\%, $\alpha=5 \% / 0,05$. Dan nilai Probabilitas 0.7428, Maka $0,05<0.7428$,hal ini berarti bahwa variable Indeks NIKKEI 225 tidak berpengaruh signifikan terhadap Indeks Harga Saham Gabungan (IHSG).

\section{Koefesien determinasi $\left(\boldsymbol{R}^{2}\right)$}

Hasil pengujian diperoleh nilai koefisien determinasi $\left(R^{2}\right)$ sebesar 0.884010 . Hal ini menunjukkan bahwa FED Rate, Inflasi, dan Indeks NIKKEI 225 mampu mempengaruhi Indeks Harga Saham Gabungan (IHSG) sebesar 88\% sedangkan sisanya 12\% dipengaruhi oleh variabel lain yang tidak termasuk dalam penelitian ini.

\section{Uji asumsi klasik}

\section{Uji normalitas}

Pengujian normalitas adalah sebuah uji yang dilakukan dengan tujuan untuk melihat sebaran data pada sebuah kelompok data atau variabel, apakah sebaran tersebut terdistrubusi normal atau tidak.

Tabel 6. Hasil regresi uji normalitas

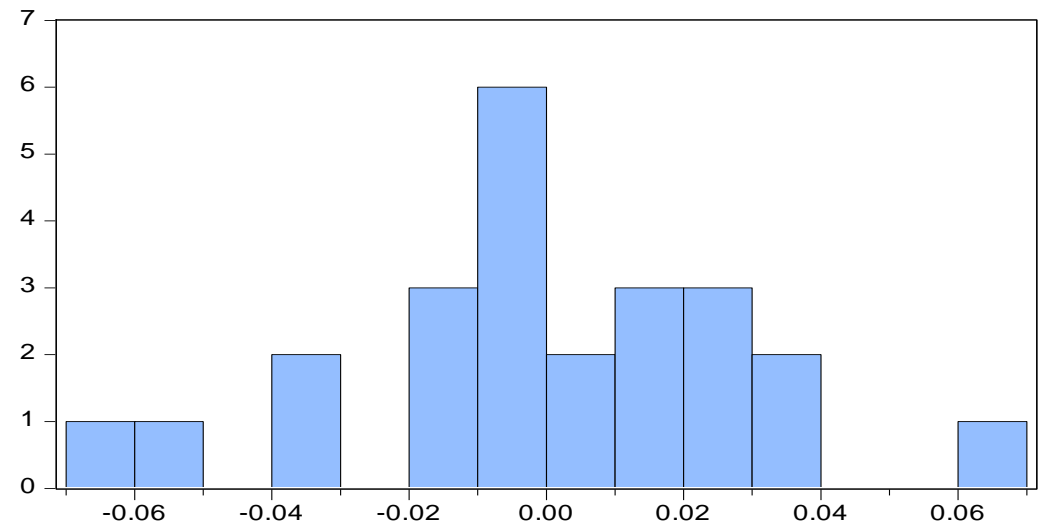

\begin{tabular}{|lc}
\hline \multicolumn{2}{l}{ Series: Residuals } \\
\multicolumn{2}{l}{ Sample 2016M01 2017M12 } \\
\multicolumn{2}{l}{ Observations 24} \\
Mean & $2.53 \mathrm{e}-16$ \\
Median & -0.004442 \\
Maximum & 0.061402 \\
Minimum & -0.060555 \\
Std. Dev. & 0.028811 \\
Skewness & -0.140715 \\
Kurtosis & 2.826381 \\
& \\
Jarque-Bera & 0.109347 \\
Probability & 0.946794 \\
\hline
\end{tabular}

Sumber: Data diolah (2019) 
Hasil penelitian ini tidak adanya masalah normalitas, dikarenakan probabilitanya sebesar $0.946794>\alpha 5 \%$ sehingga data tersebut berdistribusi normal, dan terbebas dari gejala normalitas.

\section{Hasil uji heterokedasitas}

Pengujian heterokedastisitas digunakan untuk mengetahui ada atau tidaknya penyimpangan asumsi klasik. Pengujian hetetorkedastisitas melihat ketidaksamaan varian dari residual untuk semua pengamatan pada model regresi. Persyaratan harus dipenuhi pada penelitian ini adalah probabilitas dari setiap variabel tidak signifikan agar gejala heterokedastisitas tidak terjadi

Tabel 7. Hasil uji heterokedasitas

\begin{tabular}{llll}
\hline F-statistic & 1.504525 & Prob. F(8,15) & 0.2358 \\
Obs*R-squared & 10.68452 & Prob. Chi-Square(8) & 0.2202 \\
Scaled explained SS & 6.775695 & Prob. Chi-Square(8) & 0.5610 \\
\hline
\end{tabular}

Sumber: Data diolah, 2019

Berdasarkan hasil data yang telah di uji menggunakan uji white, dapat diketahui $\mathrm{p}$ Value yang ditunjuk dengan nilai prob.Chi-Square(9) pada Obs*R-squared yaitu sebesar 0.5610 . Dengan nilai $\mathrm{p}$ value $0.5610>0,005(\alpha=5 \%)$ maka $\mathrm{H}_{0}$ diterima yang berarti bahwa model regresi bersifat homokedastisitas atau dengan kata lain model regresi terbebas dari gejala heterokedastisitas dengan tingkat kepercayaan $5 \%$.

\section{Uji multikoliniearitas}

Multikolinearitas merupakan salah satu model asumsi klasik yang melihat hubungan antara sesama variabel bebas.. Jika nilai VIF lebih besar dari 10 maka dideteksi adanya gejala multikolonearitas dalam model

Tabel 8. Hasil uji multikolinearitas

\begin{tabular}{cccc}
\hline Variable & Variance & VIF & VIF \\
\hline C & 2.049551 & 51529.52 & NA \\
FED & 0.002143 & 42.78826 & 6.307176 \\
INFLASI & 0.000219 & 75.41327 & 1.131008 \\
LNNIKKEI & 0.021791 & 52932.88 & 6.053946
\end{tabular}

Sumber: Data diolah, 2019.

Hasil regresi terlihat bahwa hubungan variabel bebas dengan variabel bebas lainnya, nilai VIF lebih kecil dari 10. Maka dideteksi tidak adanya gejala multikolonearitas dalam penelitian ini.

\section{Uji autokorelasi}

Uji Autokorelasi adalah sebuah analisis statistik yang dilakukan untuk mengetahui adakah korelasi variabel yang ada di dalam model prediksi dengan perubahan waktu

Tabel 9. Uji autokorelasi 


\begin{tabular}{lrlr}
\hline F-statistic & 0.963263 & Prob. F(2,18) & 0.4005 \\
Obs*R-squared & 2.320355 & Prob. Chi-Square(2) & 0.3134 \\
\hline
\end{tabular}

Sumber: Data diolah (2019)

Berdasarkan hasil regresi dapat diketahui bahwa nilai Pro.Chi-square(2) yang merupakan nilai $\mathrm{p}$ value dari uji Breusch-Godfrey serial Correlation LM Test, yaitu sebesar $0.3134>0,05(\alpha=5 \%)$ maka $\mathrm{H}_{0}$ diterima atau dapat dikatakan bahwa dalam model ini tidak terdapat gejala autokorelasi.

\section{KESIMPULAN DAN SARAN}

\section{Kesimpulan}

Pertumbuhan Indeks Harga Saham Gabungan (IHSG) selama periode penelitian cenderung mengalami trend yang meningkat setiap bulannya, yang menandakan bahwa Investasi di Indonesia semakin meningkat setiap bulannya. Perkembangan suku bunga The FED terus mengalami peningkatan setiap bulannya, akan tetapi kenaikannya tidak signifikan. Perkembangan tingkat Inflasi perbulan selama periode penelitian cenderung mengalami kenaikan dan penurunan, atau berfluktuatif, dan tingkat Inflasi pada 2 Tahun ini dapat dikatakan Inflasi Ringan (Creaping Inflation), karena kurang dari sepuluh persen. Perkembangan Nilai Indeks NIKKEI 225 selama periode jumlah kenaikan dan penurunan nilainya hampir sama, dengan kata lain nilai Indeks NIKKEI 225 nilainya berfluktuatif. Berdasarkan Hasil penelitian dengan menggunakan alat regresi berganda, melalui uji hipotesis secara parsial selama periode penelitian dapat diketahui bahwa The FED berpengaruh signifikan terhadap IHSG, Inflasi berpengaruh signifikan terhadap IHSG,dan Indeks NIKKEI 225 tidak berpengaruh signifikan terhadap IHSG. Sedangakan jika diuji secara simultan, bahwa FED Rate, Inflasi, dan Indeks NIKKEI $225 \mathrm{f}$ hitung > f tabel, maka secara bersama-sama berpengaruh signifikan terhadap Indeks Harga Saham Gabungan (IHSG)

\section{Saran}

Untuk Investor, harus benar-benar mengamati perkembangan Indeks Harga Saham Gabungan yang ada di Indonesia, supaya dapat mengambil langkah yang tepat sebelum melakukan investasi/Trading. Fluktuasi yang baik Indeks Harga Saham Gabungan yang ada di Indonesia dapat dijaga dengan cara menjaga laju inflasi, terus mengamati informasiinformasi terkait dengan perekonomian global, untuk dapat lebih cepat dalam mengambil tindakan yang tepat.

\section{DAFTAR PUSTAKA}

Bank Indonesia (2019), Inflasi bulanan Indonesia dalam angka Januari 2016-Desember 2017 Indonesia

Bediono. (2001). Ekonomi makro Edisi 4, BPFE : Yogyakarta

Hastuti.D; M.Edhie,Purnawan;\& S.Sunargo. (2018). Pengaruh variabel-variabel di sektor riil dan perbankan terhadap Shock Credit Default Swap (CDS) di Indonesia, eJournal Perdagangan Industri dan Moneter, 6(2), 62-80

Jogiyanto Hartono, (2010) Teori portofolio dan analisis investasi BPFE:Yogyakarta 
Mudrajad Kuncoro. (1998). Metode Kuantitatif Teori \& Aplikasi Untuk Bisnis \& Ekonomi. YKPN: Yogyakarta.

Mustika,C; E Umiyati; \& E Achmad. (2015). Analisis pengaruh ekspor neto terhadap nilai tukar rupiah terhadap dolar Amerika Serikat dan pertumbuhan ekonomi di Indonesia, Jurnal Paradigma Ekonomika, 10 (2)

RP Putri, H Heriberta, E Emilia. (2018). Pengaruh inflasi, investasi asing langsung dan pengeluaran pemerintah terhadap pertumbuhan ekonomi Indonesia, Jurnal Paradigma Ekonomika, 13 (2), 95-104

Sappeweli, Badriah. (2001). Pengaruh perubahan tingkat bunga terhadap kredit perbankan di Sulawesi Selatan. Skripsi Fakultas Ekonomi UNHAS: Makasar.

Sugiyono. (2010). Metode penelitian pendidikan pendekatan kuantitatif, kualitatif, dan $R \& D$. Alfabeta: Bandung

Syamsuddin \& Damaiyanti. (2011) Metode penelitian Pendidikan Bahasa. Angkasa: Bandung

Tandelilin, Eduardos, (2007). Analisis investasi dan manajemen portofolio edisi pertama. BPFE: Yogyakarta

Virby, Shelby. (2017). Pengaruh indeks dow jones industrial average, Nikkei 225, Hangseng Index, dan Shanghai stock exchange terhadap indeks harga saham gabungan bursa efek Indonesia Periode Tahun 2008-2013. Jurnal Ilmiah Ilmu Manajemen.4(2), 79-99, DOI: http://dx.doi.org/10.32493/Inovasi.v4i2.p\%25p.756

Witjaksono Agung, Ardian. (2010). Analisis pengaruh tingkat suku bunga SBI, harga minyak dunia, harga emas dunia, kurs rupiah, indeks Nikkei 225, dan indeks Dow Jones terhadap IHSG. Tesis, Program Studi Magister Manajemen, Universitas Dipenegoro, Semarang. 